, L. O. BJorn, M. ILyas, AND M. M. CALDWell. 1991. Changes in biologically active ultraviolet radiation reaching the earth's surface, p. 1-14. In Environmental effects of ozone depletion: 1991 update. UNEP.

MiLleR, W. L. 1994. Recent advances in the photochemistry of natural dissolved organic matter, p. 111-127. In G. R. Helz et al. [eds.], Aquatic and surface photochemistry. Lewis.

MOFFET, J. W., AND R. G. ZIKA. 1987. Reaction kinetics of hydrogen peroxide with copper and iron in seawater. Environ. Sci. Technol. 21: 804-810.

Rasmussen, J. B., L. Godbout, and M. Scallenburg. 1989. The humic content of lake water and its relationship to watershed and lake morphometry. Limnol. Oceangr. 34: 1336-1343.

Schoeberl, M. R., AND D. L. Hartmann. 1991. The dynamics of the stratospheric polar vortex and its relation to springtime ozone depletions. Science 251: 46-52.

Scully, N. M., AND D. R. S. LEAN. 1994. The attenuation of UV radiation in temperate lakes. Arch. Hydrobiol. 43: 135144.

Shao, C., W. J. Cooper, AND D. R. S. Lean. 1994. Singlet oxygen formation in lake waters from mid-latitudes, p. $215-$ 221. In G. R. Helz et al. [eds.], Aquatic and surface photochemistry. Lewis.

Shtamm, E. V., A. P. Purmal, and Y. I. Skurlatov. 1991.
The role of hydrogen peroxide in natural aquatic media. Russ. Chem. Rev. 11(60): 1228-1248.

Smart, P. L., B. L. Finlayson, W. D. Rylands, and C. M. BALL. 1976. The relation of fluorescence to dissolved organic carbon in surface waters. Water Res. 10: 805-811.

Sмith, K. C. 1989. The science of photobiology. Plenum.

Stewart, A. J., AND R. G. Wetzel. 1980. Fluorescence: absorbance ratios a molecular weight tracer of dissolved organic matter. Limnol. Oceanogr. 25: 559-564.

VINCENT, W. F., AND S. Roy. 1993. Solar ultraviolet-B radiation and aquatic primary production: Damage, protection, and recovery. Environ. Rev. 1: 1-12.

WilKINSON, L. 1990. SYSTAT: The system for statistics. Systat, Inc.

ZePP R. G., B. C. FAUST, AND J. HoIgNÉ. 1992. Hydroxyl radical formation in aqueous reactions ( $\mathrm{pH} 3-8$ ) or iron(II) with hydrogen peroxide: The photo-fenton reaction. Environ. Sci. Technol. 26: 313-319.

Zika, R. D., J. W. Moffet, R. G. Petasne, W. J. COOPER, AND E. S. SAltzman. 1985. Spatial and temporal variations of hydrogen peroxide in Gulf of Mexico waters. Geochim. Cosmochim. Acta 49: 1173-1184.

Submitted: 13 October 1994 Accepted: 1 September 1995 Amended: 21 February 1996

\title{
Nitrous oxide emissions to the atmosphere from an artificially oxygenated lake
}

\begin{abstract}
Nitrous oxide $\left(\mathrm{N}_{2} \mathrm{O}\right)$ production at the sediment surface of eutrophic Lake Baldegg was quantified with three independent methods: pore-water samplers, benthic chambers, and mass balances of the aerated-oxygenated hypolimnion. $\mathrm{N}_{2} \mathrm{O}$ production at the sediment surface was the most important source in this lake and led to an accumulation in the hypolimnion during summer stratification. Highest rates of $\mathrm{N}_{2} \mathrm{O}$ emission to the atmosphere $\left(24 \mu \mathrm{mol} \mathrm{m}^{-2} \mathrm{~d}^{-1}\right)$ were observed after the onset of winter overturn, when hypolimnetic water enriched in $\mathrm{N}_{2} \mathrm{O}$ came in contact with the atmosphere. During summer stratification $\mathrm{N}_{2} \mathrm{O}$ emissions to the atmosphere decreased to $\sim 4$ $\mu \mathrm{mol} \mathrm{m} \mathrm{m}^{-2} \mathrm{~d}^{-1}$. The winter fluxes are close to the highest reported $\mathrm{N}_{2} \mathrm{O}$ emissions from marine systems.
\end{abstract}

Nitrous oxide $\left(\mathrm{N}_{2} \mathrm{O}\right)$ contributes to global warming and catalyzes the decomposition of stratospheric ozone. Its time-integrated warming effect per unit mass (global warming potential) is $200-300$ times larger than that for $\mathrm{CO}_{2}$ (IPCC 1990). Anthropogenic $\mathrm{N}_{2} \mathrm{O}$ emissions contributed an estimated $6 \%$ to the total change in radiative forcing in the period 1980-1990. The major sink for $\mathrm{N}_{2} \mathrm{O}$ is photolysis in the stratosphere-a process that provides active chemical species for the decomposition of ozone.
At present, $\mathrm{N}_{2} \mathrm{O}$ concentration in the atmosphere (310 ppb) is increasing by $0.25 \% \mathrm{yr}^{-1}$ (IPCC 1990). Because the driving processes for this global increase are poorly understood, measurements of $\mathrm{N}_{2} \mathrm{O}$ fluxes from soils and oceans have been intensified in recent years.

$\mathrm{N}_{2} \mathrm{O}$ is produced by several microbiological processes. In natural waters nitrification and denitrification are considered to be the major processes producing $\mathrm{N}_{2} \mathrm{O}$. Law and Owens (1990) and Codispoti et al. (1993) reported significant $\mathrm{N}_{2} \mathrm{O}$ emissions from eutrophic marine systems, indicating that global $\mathrm{N}_{2} \mathrm{O}$ fluxes from aquatic systems to the atmosphere could be higher than the value of $1.4-2.8 \times 10^{12} \mathrm{~g} \mathrm{~N} \mathrm{yr}^{-1}$ proposed by Butler et al. (1989). Little is known about the significance of $\mathrm{N}_{2} \mathrm{O}$ emissions from freshwater systems. Lakes with $\mathrm{N}_{2} \mathrm{O}$ supersaturated surface waters (Yoh et al. 1988; Downes 1991), as well as eutrophic lakes that act as sinks for atmospheric $\mathrm{N}_{2} \mathrm{O}$ (Knowles et al. 1981; Lemon and Lemon 1981), have been described in the literature.

Law et al. (1992) suggested that $\mathrm{N}_{2} \mathrm{O}$ emissions from eutrophic estuaries should be considered in global $\mathrm{N}_{2} \mathrm{O}$ budgets and that $\mathrm{N}_{2} \mathrm{O}$ supersaturation in the water column resulted mainly from sedimentary sources. In our study, we chose a highly eutrophic lake with an artificially 
Table 1. Benthic fluxes $\left(\mu \mathrm{mol} \mathrm{m} \mathrm{m}^{-2} \mathrm{~d}^{-1}\right.$ ) of $\mathrm{N}_{2} \mathrm{O}, \mathrm{NO}_{3}{ }^{-}$, and $\mathrm{NH}_{4}{ }^{+}$calculated either from pore-water profiles (peeper) or from flux chamber experiments.

\begin{tabular}{|c|c|c|c|c|c|c|}
\hline Method & $\begin{array}{c}\text { Sam- } \\
\text { pling } \\
\text { site }(\mathrm{m})\end{array}$ & $\mathrm{N}_{2} \mathrm{O}^{*}$ & $\mathrm{~N}_{2} \mathrm{O} \dagger$ & $\mathrm{NO}_{3}^{-}$ & $\mathrm{NH}_{4}{ }^{+}$ & Comment \\
\hline \multicolumn{7}{|l|}{ Peeper } \\
\hline Dec 93 & 66 & 1.13 & -1.73 & -230 & 2,430 & \\
\hline Feb 94 & 66 & 0.18 & -0.19 & -210 & 4,450 & \\
\hline May 94 & 66 & 1.46 & -0.66 & -350 & 2,580 & \\
\hline Jul 94 & 30 & 4.02 & -3.78 & -380 & 2,350 & \\
\hline Jul 94 & 66 & 1.68 & -1.26 & -250 & 2,360 & \\
\hline Sep 94 & 30 & 1.89 & -0.86 & -140 & 1,890 & \\
\hline Sep 94 & 66 & & & -350 & 5,250 & \\
\hline \multicolumn{7}{|c|}{ Flux chamber $\ddagger$} \\
\hline Feb 94 & 66 & 13.5 & & $-2,920$ & 2,420 & \\
\hline Feb 94 & 66 & 11.0 & & $-3,630$ & 3,230 & \\
\hline May 94 & 66 & 11.8 & & $-5,650$ & 4,410 & \\
\hline May 94 & 66 & 13.8 & & $-5,460$ & 4,760 & \\
\hline Aug 94 & 66 & 19.3 & & $-4,540$ & 2,680 & \\
\hline Aug 94 & 66 & 17.2 & & $-2,880$ & & + ATU \\
\hline Oct 94 & 66 & 80.3 & & $-3,900$ & 4,350 & $+\mathrm{NaNO}_{3}$ \\
\hline Oct 94 & 66 & 113.0 & & $-2,830$ & & $+\mathrm{ATU},+\mathrm{NaNO}_{3}$ \\
\hline
\end{tabular}

oxygenated hypolimnion. Because $\mathrm{N}_{2} \mathrm{O}$ is nearly inert in the presence of oxygen (Broecker and Peng 1982), this lake allows us to determine benthic $\mathrm{N}_{2} \mathrm{O}$ fluxes from the $\mathrm{N}_{2} \mathrm{O}$ accumulation in the hypolimnion. We compared flux estimates from hypolimnetic mass balances with $\mathrm{N}_{2} \mathrm{O}$ fluxes obtained from pore-water profiles and from benthic chamber studies.

Lake Baldegg, a eutrophic lake in central Switzerland, has a surface area of $5.2 \mathrm{~km}^{2}$, a volume of $0.173 \mathrm{~km}^{3}$, and a maximum depth of $66 \mathrm{~m}$. The mean water residence time is $5.5 \mathrm{yr}$. The actual dissolved phosphorus concentration at overturn is $80 \mu \mathrm{g} \mathrm{P}$ liter $^{-1}$ but was as high as $460 \mu \mathrm{g} \mathrm{P}$ liter ${ }^{-1}$ in 1975 . The annual productivity was determined in 1974 and $1982-1983$ as 420 and $350 \mathrm{~g} \mathrm{C}$ $\mathrm{m}^{-2} \mathrm{yr}^{-1}$, respectively (Stadelmann 1984). During summer stratification the hypolimnion is enriched with pure oxygen; during winter, water circulation is enhanced by pumping air to deeper layers of the lake. Due to these measures the oxygen concentration always exceeded $2 \mathrm{mg}$ liter $^{-1}$ in the entire water column during our study.

The water column of Lake Baldegg was sampled at 4-week intervals between February 1994 and March 1995. $\mathrm{N}_{2} \mathrm{O}$ concentrations were analyzed by headspace gas chromatography and an electron capture detector. The sediment pore water was sampled six times at two different depths with dialysis pore-water samplers ("peepers"). Design and deployment of peepers has been described by Hesslein (1976). We modified the peeper in such a way that it could be covered gastight in situ at the lake bottom. Two stainless steel lids were released by a burning wire after a 3-week exposure. Magnets kept the lids closed. To sample the pecper, we injected helium through butyl septa and transferred the displaced water into gastight syringes within $1 \mathrm{~h}$ after retrieval. This procedure allows sampling of the peepers without substantial loss of $\mathrm{N}_{2} \mathrm{O}$ and without air contamination.

Fluxes of $\mathrm{N}_{2} \mathrm{O}$ across the sediment-water interface were measured four times with the aid of an in situ flux chamber (Devol 1987). The instrument contains two stainless steel flux chambers that cover sediment areas of $400 \mathrm{~cm}^{2}$ and typically enclose 3-6 liters of water. After lowering the instrument to the sediment surface, an electronic system triggers up to 15 mechanical functions. From each chamber, 10 samples of $\sim 50 \mathrm{ml}$ were drawn at preprogrammed time intervals. During the experiment the enclosed water in the chambers was mixed by a rotating stirrer. We used stirring velocities of $\sim 1 \mathrm{rpm}$, resulting in a diffusive boundary-layer thickness of $\sim 1 \mathrm{~mm}$ (Wehrli et al. in prep.). At the end of the experiment the grab shovels at the bottom of the chambers were closed and two box sediment cores of about $30 \mathrm{~cm}$ were retrieved.

The flux chamber experiments lasted $40-60 \mathrm{~h}$, during which time 10 samples were taken in parallel from each of the two flux chambers at time intervals of 2-8 h. At the end of all four experiments, oxygen was depleted in the chambers. Because the oxygen concentration is a key variable of the production and consumption of $\mathrm{N}_{2} \mathrm{O}$ by nitrification and denitrification (Downes 1988), the $\mathrm{N}_{2} \mathrm{O}$ flux across the sediment surface is likely to change during the experiment. To minimize this change, we considered only samples that were drawn during the first $8 \mathrm{~h}$ of the experiment for flux calculations. Dates and sampling sites of all flux chamber experiments and peeper deployments are summarized in Table 1. In two flux chamber experiments we injected allylthiourea $\left(20 \mathrm{mg} \mathrm{litcr}^{-1}\right.$ in the flux chamber), a known nitrification inhibitor (Hall 1984), 


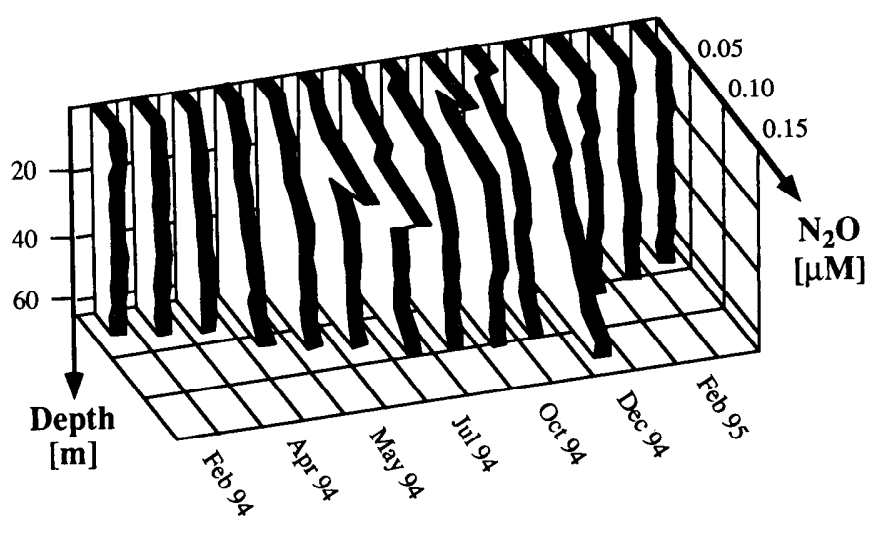

Fig. 1. $\mathrm{N}_{2} \mathrm{O}$ in the water column of Lake Baldegg, February 1994-March 1995.

into one of the flux chambers. In another experiment we injected $\mathrm{NaNO}_{3}$ into both flux chambers to increase the ambient $\mathrm{NO}_{3}{ }^{-}$concentration from 120 to $240 \mu \mathrm{M}$.

Profiles of $\mathrm{N}_{2} \mathrm{O}$ concentration in the water column are presented in Fig. 1. Hypolimnetic concentrations increased as soon as stratification developed in spring. Highest concentrations $(\sim 0.13 \mu \mathrm{M})$ were observed in December. Because the saturation value for water in equilibrium with atmospheric $\mathrm{N}_{2} \mathrm{O}$ is $14.3 \times 10^{-3} \mu \mathrm{M}$ at $6.2^{\circ} \mathrm{C}$ (calculated from solubility constants, Weiss and Price 1980 , and an assumed atmospheric $\mathrm{N}_{2} \mathrm{O}$ concentration of $310 \mathrm{ppb}$ ), this value exceeded saturation more than 9-fold. Many profiles show increasing concentrations toward the sediment surface, indicating that the sedimentwater interface represented a source for $\mathrm{N}_{2} \mathrm{O}$. In June and July, we observed peak concentrations in the region of the thermocline, which points toward a second $\mathrm{N}_{2} \mathrm{O}$ source in the metalimnion. These peak concentrations coincided with oxygen minima. $\mathrm{N}_{2} \mathrm{O}$ concentrations at the lake surface were always supersaturated. $\mathrm{N}_{2} \mathrm{O}$ concentrations in the surface water were higher during winter overturn than during summer stagnation. The highest concentrations were measured in October. After the onset of winter overturn in December, the $\mathrm{N}_{2} \mathrm{O}$ content of the lake decreased.

Figure 2 shows typical pore-water profiles. The vertical resolution for $\mathrm{N}_{2} \mathrm{O}$ was $1 \mathrm{~cm}$; for $\mathrm{NO}_{3}{ }^{-}$and $\mathrm{NH}_{4}{ }^{+}$, it was $0.5 \mathrm{~cm}$. All pore-water profiles (four at $66-\mathrm{m}$, two at $30-\mathrm{m}$ water depth) exhibited a $\mathrm{N}_{2} \mathrm{O}$ peak at the sediment surface. Concentrations $(1.4 \mu \mathrm{M})$ were highest in summer, although no obvious seasonality was observed. Profiles at 30- and 66-m depth did not differ significantly. The $\mathrm{NO}_{3}{ }^{-}$profile suggested $\mathrm{NO}_{3}{ }^{-}$consumption in the region of the sediment-water interface. $\mathrm{NO}_{3}{ }^{-}$is consumed at the sediment surface or in the top sediment layer by denitrification and $\mathrm{NO}_{3}{ }^{-}$ammonification. $\mathrm{NH}_{4}{ }^{+}$diffuses from deeper sediments to the sediment surface and eventually to the overlying water where it likely would be oxidized to $\mathrm{NO}_{3}{ }^{-}$by nitrifiers. Because nitrification, as well as denitrification, produces $\mathrm{N}_{2} \mathrm{O}$ as an intermediate product or by-product (Downes 1988), the dominant process producing $\mathrm{N}_{2} \mathrm{O}$ cannot be identified from pore-water profiles.

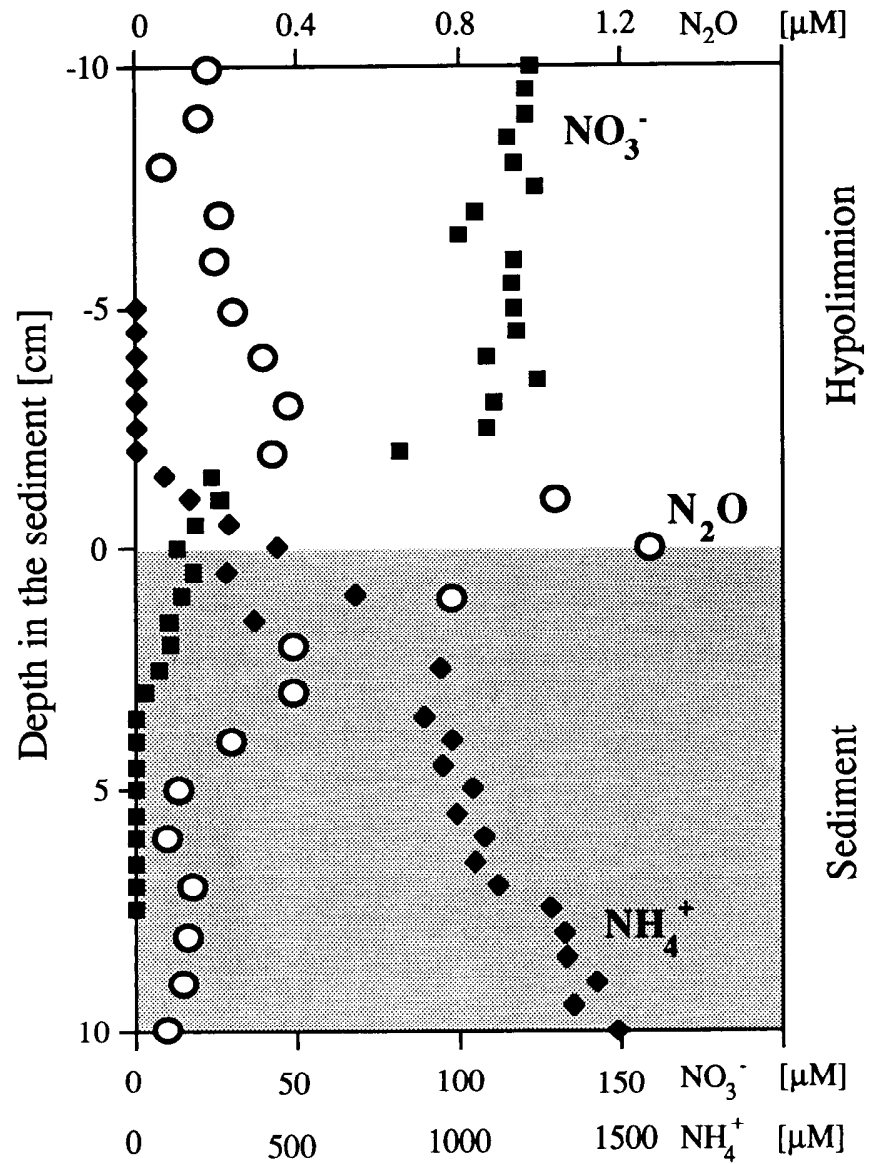

Fig. 2. $\mathrm{N}_{2} \mathrm{O}, \mathrm{NO}_{3}{ }^{-}$, and $\mathrm{NH}_{4}{ }^{+}$at the sediment surface of Lake Baldegg, 30-m depth, July 1994.

Figure 3 shows a typical result from a flux chamber experiment. $\mathrm{N}_{2} \mathrm{O}$ concentrations in the flux chamber increased in all four experiments during the first $8 \mathrm{~h}$. The increase in concentration, however, varied significantly between experiments. Allylthiourea, known to inhibit nitrification, did not influence $\mathrm{N}_{2} \mathrm{O}$ production in the flux chamber. In the experiment with artificially increased $\mathrm{NO}_{3}{ }^{-}$concentrations (from 120 to $240 \mu \mathrm{M}$ ), the $\mathrm{N}_{2} \mathrm{O}$ flux $\left(100 \mu \mathrm{mol} \mathrm{m}^{-2} \mathrm{~d}^{-1}\right)$ was five times larger than the average value of the other three flux chamber experiments (19 $\mu \mathrm{mol} \mathrm{m}{ }^{-2} \mathrm{~d}^{-1}$ ). Because allylthiourea showed no effect, but $\mathrm{NO}_{3}{ }^{-}$addition increased $\mathrm{N}_{2} \mathrm{O}$ production, denitrification rather than nitrification is likely the dominant source of $\mathrm{N}_{2} \mathrm{O}$.

Applying Fick's first law, $F=\phi \times D \times \mathrm{d} C / \mathrm{d} z$ (where $\phi$ is porosity, $D$ is the diffusion coefficient, and $\mathrm{d} C / \mathrm{d} z$ the concentration gradient), to the pore-water profiles we calculated the flux $(F)$ of $\mathrm{N}_{2} \mathrm{O}$ across the sediment surface. For $\phi$ we used a value of 0.92 and for $D$ the molecular diffusion coefficient $1.08 \times 10^{-5} \mathrm{~cm}^{2} \mathrm{~s}^{-1}\left(5^{\circ} \mathrm{C}\right.$, Lerman 1979). Fluxes based on the flux chamber experiments were calculated directly from the change in concentration in the overlying water during the first $8 \mathrm{~h}$, taking into account the enclosed water volume and the surface area of the sediment in contact with it.

Fluxes of $\mathrm{N}_{2} \mathrm{O}, \mathrm{NO}_{3}{ }^{-}$, and $\mathrm{NH}_{4}{ }^{+}$estimated either from 


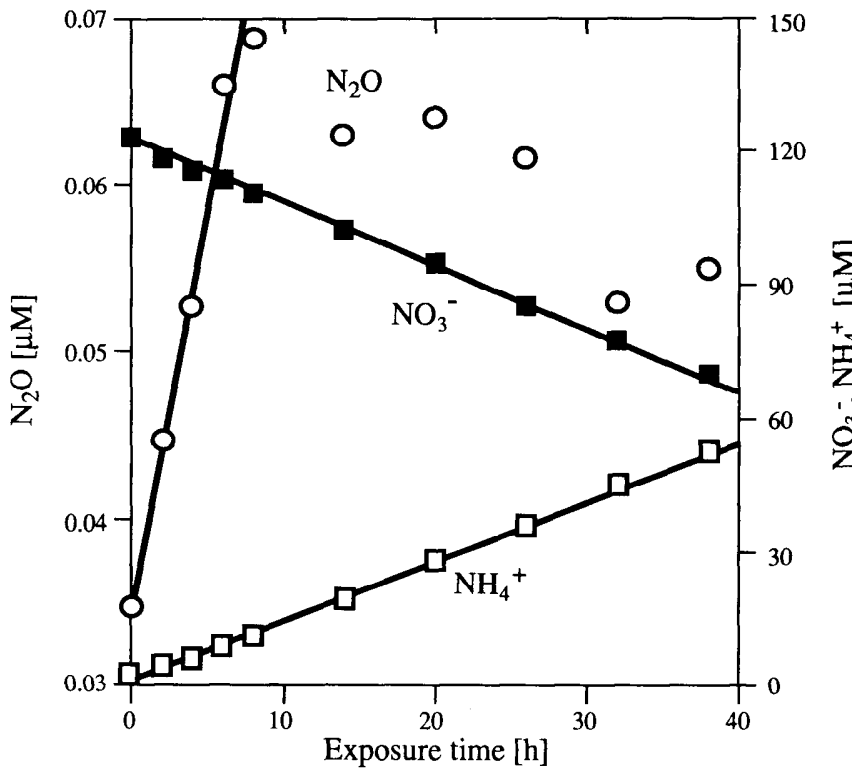

Fig. 3. $\mathrm{N}_{2} \mathrm{O}, \mathrm{NO}_{3}{ }^{-}$, and $\mathrm{NH}_{4}{ }^{+}$in the flux chamber, Lake Baldegg, 66-m depth, March 1994.

pore-water profiles or from flux chamber experiments are summarized in Tablc 1. Fluxes for $\mathrm{NH}_{4}{ }^{+}$calculated from the two methods agreed well, whereas those for $\mathrm{N}_{2} \mathrm{O}$ and $\mathrm{NO}_{3}{ }^{-}$differed more than 10 -fold. In the case of $\mathrm{N}_{2} \mathrm{O}$ and $\mathrm{NO}_{3}{ }^{-}$, fluxes calculated from pore-water profiles may be underestimated for two reasons. First, due to insufficient vertical resolution, fluxes based on pore-water profiles often fail to reflect redox processes occurring in the top few millimeters of the sediment. Second, we considered the molecular diffusion coefficient to estimate fluxes, although the concentration gradients of $\mathrm{N}_{2} \mathrm{O}$ and $\mathrm{NO}_{3}{ }^{-}$ extended from the sediment into the overlying water where turbulent mixing should be taken into account. In the case of $\mathrm{NH}_{4}{ }^{+}$however, the gradients are mainly in the top layer of the sediments where only molecular diffusion must be considered. Fluxes based on flux chamber experiments may overestimate in situ fluxes due to the mixing of the overlying water by a mechanical stirrer. The real $\mathrm{N}_{2} \mathrm{O}$ fluxes across the sediment-water interface are constrained by the results of the two methods. The peepers yield a lower limit (avg value, $2 \mu \mathrm{mol} \mathrm{m}^{-2} \mathrm{~d}^{-1}$ ) and the flux chamber data represent an upper boundary (avg value, $19 \mu \mathrm{mol} \mathrm{m}^{-2} \mathrm{~d}^{-1}$ ).

Because $\mathrm{N}_{2} \mathrm{O}$ is rather inert in oxic lake and seawater, most of the $\mathrm{N}_{2} \mathrm{O}$ diffusing from the sediment surface into the lake accumulates in the hypolimnetic water during summer stratification. From May to October, the average increase of the hypolimnetic $\mathrm{N}_{2} \mathrm{O}$ content yielded $60 \mathrm{~mol}$ $\mathrm{d}^{-1}$. From the concentration gradients in the thermocline $\left(5 \times 10^{-3} \mu \mathrm{M} \mathrm{m}^{-1}\right)$ and the depth-dependent vertical diffusion coefficients of $\sim 1-3 \times 10^{-6} \mathrm{~m}^{2} \mathrm{~s}^{-1}$ (calculated with the heat budget method, Powell and Jassby 1974) we calculated a flux of 1.7-5.3 mol $\mathrm{N}_{2} \mathrm{O} \mathrm{d}^{-1}$ from the hypolimnion into the epilimnion. Therefore, total production in the hypolimnion ranged from 60 to $65 \mathrm{~mol} \mathrm{~d}^{-1}$, or 11 to $13 \mu \mathrm{mol} \mathrm{m}-2 \mathrm{~d}^{-1}$. This value lies well within the

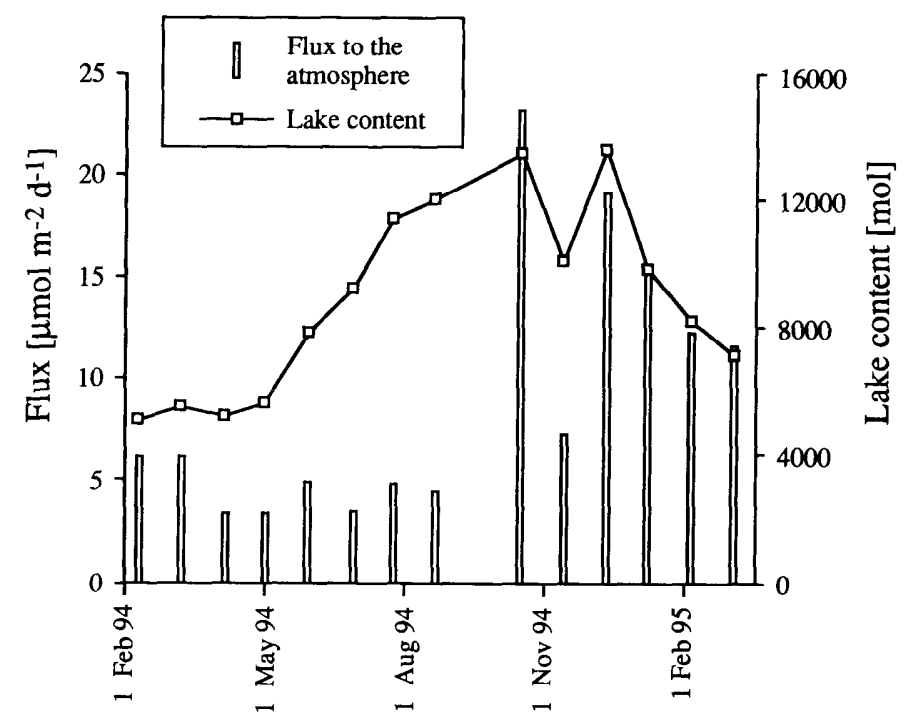

Fig. 4. $\mathrm{N}_{2} \mathrm{O}$ content and flux to the atmosphere of Lake Baldegg, February 1994-March 1995.

range of our flux measurements with the peeper and flux chamber method and indicates that the sediment surface is the dominant source of $\mathrm{N}_{2} \mathrm{O}$ in the hypolimnion. A sharp negative $\mathrm{N}_{2} \mathrm{O}$ concentration gradient was always observed below the sediment-water interface, suggesting a sink for $\mathrm{N}_{2} \mathrm{O}\left(1.4 \mu \mathrm{mol} \mathrm{m}^{-2} \mathrm{~d}^{-1}\right)$ in these anoxic deeper sediment layers. $\mathrm{N}_{2} \mathrm{O}$ probably is reduced to $\mathrm{N}_{2}$ by denitrifiers.

The surface waters of the lake were always supersaturated with respect to atmospheric $\mathrm{N}_{2} \mathrm{O}$ concentrations during our 1-yr study. The $\mathrm{N}_{2} \mathrm{O}$ fluxes from the lake into the atmosphere were calculated with

$$
F=v_{\text {tot }} \times\left(c_{w}-c_{s}\right)\left(\mathrm{mol} \mathrm{m}^{-2} \mathrm{~d}^{-1}\right),
$$

based on the stagnant boundary theory. $v_{\text {tot }}$ represents the transfer velocity, $c_{w}$ the surface concentration, and $c_{s}$ the concentration in equilibrium with the atmosphere, calculated with solubility constants from Weiss and Price (1980) and an assumed atmospheric $\mathrm{N}_{2} \mathrm{O}$ concentration of $310 \mathrm{ppb}$.

For Lake Baldegg an average $v_{\text {tot }}\left(0.4 \mathrm{~m} \mathrm{~d}^{-1}\right)$ for $\mathrm{O}_{2}$ was determined from oxygen budget calculations during winter overturn. Because the gas exchange of both $\mathrm{N}_{2} \mathrm{O}$ and $\mathrm{O}_{2}$ is dominated by transfer through the water boundary layer, we calculated the transfer velocity for $\mathrm{N}_{2} \mathrm{O}$ with the formula (Schwarzenbach ct al. 1993)

$$
v_{\text {tot }}{ }^{\mathrm{N}^{2} \mathrm{O}}=v_{\mathrm{tot}} \mathrm{O}_{2} \times\left(D_{w} \mathrm{~N}_{2} \mathrm{O} / D_{w} \mathrm{O}_{2}\right)^{0.5} \approx 0.4 \mathrm{~m} \mathrm{~d}^{-1} .
$$

$D_{w}$ is the molecular diffusion coefficient in water $\left(\mathrm{N}_{2} \mathrm{O}=\right.$ $1.08 \times 10^{-5} \mathrm{~cm}^{2} \mathrm{~s}^{-1}, \mathrm{O}_{2}=1.26 \times 10^{-5} \mathrm{~cm}^{2} \mathrm{~s}^{-1}, 5^{\circ} \mathrm{C}$, Lerman 1979). The resulting $\mathrm{N}_{2} \mathrm{O}$ emission rates are presented in Fig. 4. Emissions were larger from October 1994 to March 1995 than from February 1994 to September 1994. These larger emissions are likely due to increased mixing that transported hypolimnetic water enriched with $\mathrm{N}_{2} \mathrm{O}$ to the epilimnion during overturn and thus increased the $\mathrm{N}_{2} \mathrm{O}$ concentration at the lake surface. As a conse- 
Table 2. $\mathrm{N}_{2} \mathrm{O}$ emissions to the atmosphere from aquatic systems.

\begin{tabular}{lcl}
\hline \multicolumn{1}{c}{ Region } & $\begin{array}{c}\mathrm{N}_{2} \mathrm{O} \text { emission } \\
\left(\mu \mathrm{mol} \mathrm{m} \mathrm{d}^{-1}\right)\end{array}$ & \multicolumn{1}{c}{ Reference } \\
\hline Marine systems & & \\
Average marine emission & 0.6 & $\begin{array}{l}\text { Butler et al. 1989 } \\
\text { Law and Owens 1990 }\end{array}$ \\
NW Indian Ocean (upwelling region) & $9-16$ & Codispoti et al. 1993 \\
E Pacific (Peruvian upwelling region) & 39 & Law et al. 1992 \\
Tamar Estuary, U.K. & $7-12$ & \\
Lakes & & Lemon and Lemon 1981 \\
Laurentian Great Lakes & \pm 77 & Downes 1991 \\
Lake Okaro, N.Z. & 0.6 & This study \\
Lake Baldegg, Switzerland & $8-16$ & \\
\hline
\end{tabular}

quence of increased emissions, the $\mathrm{N}_{2} \mathrm{O}$ content of the lake decreased from $13.6 \times 10^{3} \mathrm{~mol}$ in December 1994 to $7.1 \times 10^{3} \mathrm{~mol}$ in March 1995 . However, the lake as a whole remained supersaturated because at $5.2^{\circ} \mathrm{C}$ (lake temperature in March 1995) the equilibrium concentration would be $\sim 15 \times 10^{-3} \mu \mathrm{M}$, which corresponds to a lake content of $2.6 \times 10^{3} \mathrm{~mol} \mathrm{~N}_{2} \mathrm{O} . \mathrm{N}_{2} \mathrm{O}$ production at the sediment surface during winter and the slow gas exchange accounts for this nonequilibrium even at the end of spring overturn. The aeration of this lake does not significantly enhance the gas exchange (Wüest et al. 1992). The $\mathrm{N}_{2} \mathrm{O}$ fluxes into the atmosphere are smaller during summer stratification with an average value of $4 \mu \mathrm{mol} \mathrm{m}^{-2} \mathrm{~d}^{-1}$.

The $\mathrm{N}_{2} \mathrm{O}$ profile in October suggests either a source of $\mathrm{N}_{2} \mathrm{O}$ close to the lake surface or a zone of $\mathrm{N}_{2} \mathrm{O}$ consumption at a depth of $\sim 8 \mathrm{~m}$. Law et al. (1993) showed with incubation experiments that denitrification coupled with $\mathrm{N}_{2} \mathrm{O}$ production in aerobic surface waters can enhance the sediment $\mathrm{N}_{2} \mathrm{O}$ flux by $150-500 \%$ in eutrophic estuaries. The concentration peaks at a depth of 10-20 $\mathrm{m}$ in June and July suggest a second source of $\mathrm{N}_{2} \mathrm{O}$ in the water column. Such $\mathrm{N}_{2} \mathrm{O}$ maxima that coincide with oxygen minima are often observed in oceans and usually are attributed to $\mathrm{N}_{2} \mathrm{O}$ production through nitrification in the water column (Butler et al. 1989). Knowles et al. (1981) also observed such $\mathrm{N}_{2} \mathrm{O}$ maxima at the thermocline in Lake Erie and suggested nitrification to be the source of this $\mathrm{N}_{2} \mathrm{O}$.

Combining our various observations, we conclude that the sediment surface is the major source of $\mathrm{N}_{2} \mathrm{O}$ (11-13 $\mu \mathrm{mol} \mathrm{m} \mathrm{m}^{-2} \mathrm{~d}^{-1}$ ) in Lake Baldegg. On a yearly average, the lake exports 8-16 $\mu \mathrm{mol} \mathrm{N}_{2} \mathrm{O} \mathrm{m}^{-2} \mathrm{~d}^{-1}$ into the atmosphere and 1-2 $\mu \mathrm{mol} \mathrm{N}_{2} \mathrm{O} \mathrm{m}^{-2} \mathrm{~d}^{-1}$ to the deeper sediments. These emissions to the atmosphere are of the same order of magnitude as the highest $\mathrm{N}_{2} \mathrm{O}$ emissions reported that were found in estuaries and marine upwelling zones ( $\mathrm{Ta}$ ble 2). With respect to the nitrogen cycle of Lake Baldegg, the $\mathrm{N}_{2} \mathrm{O}$ emissions are unimportant because they represent only $0.2 \%$ of the total nitrogen input into the lake and $\sim 0.3 \%$ of the estimated $\mathrm{N}_{2}$ fluxes from the lake to the atmosphere (Höhener and Gächter 1993).

Lake Baldegg is a highly eutrophic lake and is artificially oxygenated, so our results cannot be extrapolated to the global surface area of lakes. The impact of artificial oxygenation on fluxes of different nitrogen species across the sediment-water interface have been studied in detail in Lake Sempach (Höhener and Gächter 1994). Lake Sempach, a eutrophic 87-m-deep lake in central Switzerland, is $\sim 8 \mathrm{~km}$ southwest of Lake Baldegg. Its trophic state is similar to that of Baldegg and, since 1984, the hypolimnion of Sempach has been oxygenated and artificially mixed by the same technique as applied in Baldegg. Höhener and Gächter (1994) found that artificial oxygenation of the hypolimnion increased benthic denitrification rates. They speculated that this was due to the presence of Beggiatoa at the sediment surface. This bacterium, known to oxidize $\mathrm{H}_{2} \mathrm{~S}$, was not present in the pelagic sediment of Baldegg and Sempach before artificial oxygenation began. By oxidizing $\mathrm{H}_{2} \mathrm{~S}$, Beggiatoa detoxifies the cnvironment for nitrifying bacteria at the sediment surface. As a consequence, the distance between the sites of $\mathrm{NO}_{3}{ }^{-}$generation through nitrification and $\mathrm{NO}_{3}{ }^{-}$ reduction through denitrification decreased. The resulting steeper $\mathrm{NO}_{3}{ }^{-}$gradients allowed an enhanced overall denitrification rate.

We postulate higher denitrification rates in Lake Baldegg as a consequence of artificial mixing and oxygenation, so $\mathrm{N}_{2} \mathrm{O}$ production by benthic denitrification might also be enhanced in Baldegg compared to other eutrophic lakes. In eutrophic marine or freshwater systems, anoxic deep waters mostly act as a sink for $\mathrm{N}_{2} \mathrm{O}$ produced either by nitrification or denitrification at the transient zone between oxic and anoxic water layers (Broecker and Peng 1982; Codispoti et al. 1993; Downes 1991; Knowles et al. 1981). Therefore, artificial oxygenation of the hypolimnion of Lake Baldegg not only may have increased $\mathrm{N}_{2} \mathrm{O}$ production at the sediment surface but also eliminated anoxic conditions in the hypolimnion that formerly favored $\mathrm{N}_{2} \mathrm{O}$ reduction. As a consequence, artificial oxygenation might increase net production of $\mathrm{N}_{2} \mathrm{O}$ and therefore increase $\mathrm{N}_{2} \mathrm{O}$ emissions to the atmosphere.

Martin Mengis René Gächter Bernhard Wehrli

Limnological Research Center CH-6047 Kastanienbaum, Switzerland EAWAG/ETH 


\section{Acknowledgments}

We thank M. Bott, C. Dinkel, G. Friedl, G. Glod, T. Mares, and $T$. Schaller for help with fieldwork, and M. Downes, N. Urban, A. Wuest, and two anonymous referees for helpful suggestions.

\section{References}

Broecker, W. S., And T. H. Peng. 1982. Tracers in the sea. Eldigio.

Butler, J. H., J. W. Elkins, T. H. ThOMSON, AND K. B. Egan. 1989. Tropospheric and dissolved $\mathrm{N}_{2} \mathrm{O}$ of the West Pacific and East Indian Oceans during the El Niño Southern Oscillation event of 1987. J. Geophys. Res. 94: 14,865-14,877.

CODISPOTI, L. A., AND OTHERs. 1993. On the nitrous oxide flux from production regions that contain low oxygen waters, p. 271-284. In B. N. Desai [ed.], Oceanography of the Indian Ocean. Balkema.

Devol, A. 1987. Verification of flux measurements made with in situ benthic chambers. Deep-Sea Res. 34: 1007-1026.

DOWNES, M. T. 1988. Aquatic nitrogen transformations at low oxygen concentrations. Appl. Environ. Microbiol. 54: $172-175$

-. 1991. The production and consumption of nitrate in an eutrophic lake during early stratification. Arch. Hydrolbiol. 122: 257-274.

HALL, G. H. 1984. Measurements of nitrification rates in lake sediments: Comparison of the nitrification inhibitors nitrapyrin and allylthiourea. Microb. Ecol. 10: 25-36.

HessLEIN, R. H. 1976. An in situ sampler for close interval pore water studies. Limnol. Oceanogr. 21: 912-914.

HöHENER, P., AND R. GÄCHTER. 1993. Prediction of dissolved inorganic nitrogen (DIN) concentrations in deep, seasonally stratified lakes based on rates of DIN input and $\mathrm{N}$ removal processes. Aquat. Sci. 55: 112-131.

$\longrightarrow$, AND — 1994. Nitrogen cycling across the sedi- ment-water interface in a eutrophic, artificially oxygenated lake. Aquat. Sci. 56: 115-132.

IPCC (INTERgovernmental PANel ON Climate Change). 1990. Climate change. Cambridge.

KNowles, R., D. R. S. Lean, AND Y. K. Chan. 1981. Nitrous oxide concentrations in lakes: Variations with depth and time. Limnol. Oceanogr. 26: 855-866.

LAW, C. S., AND N. J. P. OwENs. 1990. Significant flux of atmospheric nitrous oxide from the northwest Indian Ocean. Nature 346: 826-828.

, A. P. Rees, AND N. J. P. Owens. 1992. Nitrous oxide: Estuarine sources and atmospheric flux. Estuarine Coastal Shelf Sci. 35: 301-314.

, AND - 1993. Nitrous oxide production by estuarine epiphyton. Limnol. Oceanogr. 38: 435-441.

LEMON, E., AND D. LEMON. 1981. Nitrous oxide concentrations in freshwaters of the Great Lakes basin. Limnol. Oceanogr. 26: 867-879.

LERMAN, A. 1979. Geochemical processes: Water and sediment environments. Wiley.

Powell, T., AND A. JASSBY. 1974. The estimation of vertical eddy diffusivities below the thermocline in lakes. Water Resour. Res. 10: 191-198.

SCHWARZENBACH, R. P., P. M. GSCHWEND, AND D. M. IMBODEN. 1993. Environmental organic chemistry, 1st ed. Wiley.

StadelmanN, P. 1984. Die Zustandsentwicklung des Baldeggersees (1900 bis 1980) und die Auswirkungen von seeintcrnen Massnahmen. Wasser Energie Luft 5/6: 84-95.

WeIss, R. F., AND B. A. PRICE. 1980. Nitrous oxide solubility in water and seawater. Mar. Chem. 8: 347-359.

Wüest, A., N. H. BRoOKS, AND D. M. IMBoden. 1992. Bubble plume modeling for lake restoration. Water Resour. Res. 28: 3235-3250.

Yoh, M., H. Terai, and Y. Sauio. 1988. Nitrous oxide in freshwater lakes. Arch. Hydrobiol. 113: 273-294.

Submitted: 4 May 1995

Accepted: 22 November 1995 Amended: 24 January 1996

\section{Pelagic responses to changes in dissolved organic carbon following division of a seepage lake}

\begin{abstract}
Within 2 yr of dividing a multibasin lake into discrete lakes for experimentation, dissolved organic carbon (DOC) concentrations and water color (absorption coefficient $g$ at $440 \mathrm{~nm}, g_{440}$ ) increased in the east basin and decreased slightly in the west basin. These changes were not explainable by watershed vegetation or groundwater chemical composition. However, $g_{440}$ increased from 0.7 to $4.2 \mathrm{~m}^{-1}$ for water moving through the sediment-water interface in the east basin. In the west basin, $g_{440}$ of groundwater $\left(0.6 \mathrm{~m}^{-1}\right)$, in-seeping water $\left(0.7 \mathrm{~m}^{-1}\right)$, and lake water $\left(0.7 \mathrm{~m}^{-1}\right)$ were all similar. Patterns of DOC distribution matched time trends in the surface waters. In the east basin, DOC concentration doubled and $g_{440}$ increased 3-fold from 1990 to 1993 . Trends in the west basin were more complex, but in general, there was a decrease in DOC and $g_{440}$ over the same period. Changes in the light regime affected phytoplankton vertical distribution, but total areal chlorophyll
\end{abstract}

and epilimnetic chlorophyll concentrations were not altered. The depth of oxygenation was changed by altered mixing characteristics and phytoplankton distribution. Changes in light-attenuating DOC affected pelagic responses to nutrient inputs.

Dissolved organic carbon (DOC) plays multiple and pivotal roles in lake ecosystems (Wetzel 1992; Schindler et al. 1992). Allochthonous DOC is rich in colored, relatively refractory components (Thurman 1985) that have significant effects on physical and chemical processes and ecosystem structure (Jones 1992). This refractory DOC alters light penetration, $\mathrm{pH}$, and trace metal and nutrient availability (Jackson and Hecky 1980; Jones 1992). Staining by DOC decreases phytoplankton production (Jack- 